\title{
BODY SCHEME - FUNDAMENTAL COMPONENT OF GROWTH AND DEVELOPMENT
}

\author{
Abalașei Beatrice ${ }^{1 *}$ \\ Popescu Lucian ${ }^{2}$ \\ 1,2"Alexandru loan Cuza" University of Iasi, 3.Toma Cozma, 700584, Romania
}

Keywords: psychomotricity, body scheme, growth and development

\begin{abstract}
Body scheme plays a crucial role in child development. This influences both the growth and the development of the individual. If the scheme is properly integrated body, the individual will develop harmoniously, but if there are disturbances of body schema, it can interfere with the growth and development of the child. Body scheme is an element underpinning the construction of individual personality, is vital to this process and enhancing self-esteem. Investigative approach comes to prove the correlation between body scheme in line with the maturing child. The previous statement is the premise of research and will be verified by two tests. Call and send test results relevant to the objective of the research: a well-defined scheme favors body location in space, the execution of daily actions and relationships with people around you.
\end{abstract}

\section{Introduction}

Body scheme is, F. Lauzon (1990, as cited in Albu, 1999, p. 64) own body image, its place in space and its possibilities for action in relation to people and objects in the environment. For Thomas R. (1996), body scheme is "feeling physicality" conscience positions and attitudes based on experience and made many thanks intero and exteroceptive information. (as cited in Ochiană, 2006, p. 60 ). Some authors equate body schema and body image. In neurology, body image is meant by integration in the brain of an acquisition. The integration process involves the identification, location and orientation in space of different body segments. In this case it is preferable to use the concept of body schema. Body image concerns how the perception of one's body, is a concept used by psychologists. Author H. Wallon (1973, p. 47) states that the body scheme is a basic element indispensable for building the child's personality is represented more or less differentiated child has of his own body.

The classic definition given by A. Porot (as cited in Albu, 1999, p. 38) is "the image that each has on his body, partial or total image perceived in static or

*E-mail: beatrice.abalasei@uaic.ro, tel. 0040745350332 
dynamic state of the body or the ratio between them and, especially, its relations with space and the surrounding environment" (Albu \& Albu, 1999, p. 23).

Scheme body builds, develops, formed bit by bit due to acquisitions sensitive, sensory, visual and kinesthetic. A well designed scheme favours body location in space, the execution of daily actions and relationships with people around. A. Lapierre (1972, p. 81) believes that by making body scheme appears consistent proprioceptive perception, which gives the internal image of self, and the exteroceptive (visual perception, tactile and auditory), which gives an external self. That formal compliance occurs during the driving experiences of early childhood; the child acquires catching and then realized walking. Repeating these experiences lead to establishing and determining an accurate image of the body, separate image or integrated into the surrounding space. Relations "interperceptive" will appear in these experiences driving and enhanced traction detachment from abstract thinking to form. Training the body scheme depends on: the acquisition time orientation, laterality and language reflected image. In this regard, the scheme is not only physical data acquisition or perceptual representations; it stores information to define the unit body. Determinants of body scheme are: sensory information (tactile sensations, thermal, painful), the integration of neurophysiological, integrating cognitive (contribution intelligence and motor processes mnemonic), understanding their side, the role of social models ontogenetic evolution (social factors) and emotional experiences in relation to corporeality (affective factors).

Through the process of growth means quantitative level of individual somatic indicators, level influenced by genetic and environmental factors action. The increase must be seen in all its complexity as it is a basic characteristic of living organisms.

By means developing the quality of individual somatic indices, level dependent action of hereditary factors and the environment in which education plays an important role. The development should be seen as an increase in complexity of the structure and functions as a morphological and functional maturation orientation. The development process is based on certain phenomena that occur at various organizational levels such as at the cellular, sub-cellular, tissue, whole body and to the human community.

Physical development of the individual is closely related to baggage motor of the individual, consists of abilities, skills and qualities driving and harmony between clues morphological (somatic) and the functional proportionality between them, these leading to higher development indexes morphological and functional of the body. In this context, intellectual development is responsible for the acquisition of information (forms of energy) that invades the senses, information collected from the environment or from prior knowledge (information acquired from their parents and sent to children through genes).

"The child is at first only capable of movement in the block, withdrawal or appropriation of twists and contortions global or accidental whole body. From this amorphous matrix gradually emerge finer activities” (Gordon, 1997, p. 107). 
The development is a complex process of transition from unknown to known, from simple to complex, from the abstract to familiar, from an inferior to a superior, which takes place in different stages. The transition from one stage to another is characterized by qualitative leaps and quantitative accumulation, these phenomena being in a relationship of interdependence. The development has an ascending character, like a spiral, with apparent setbacks and comebacks. Being a progressive process, development is always the result of the contradictions that arise between the capabilities it holds an individual at a time, and the requirements of increasingly complex social and material factors highlighted by influencing its development.

\section{Material and methods}

Objective This paper aims to show tangible contribution scheme in the processes of growth and development.

Hypothesis We believe that a properly integrated body scheme, visible in designing child drawing, reflects normal growth and development.

Method Test Goodenough provides clues about the child's intellectual level and depending on the level of psychomotor maturity. Drawing the little man appear indices that can be significant for cognitive development, specifically assessed by the degree of perfection and completeness of the design, the overall balance, richness of detail (Abraham, 2004).

This research was conducted over a period of nine months and our subject was a little girl: 6 years old. We were applied two series of tests, initial and final, based on which we can see the relationship between development and the child's body scheme (initial test: 15/02/2016, final test: 10/06/2016).

\section{Results and Discussions}

Table 1. Goodenough

\begin{tabular}{|c|l|c|}
\hline \multicolumn{3}{|c|}{ Goodenough- recognize the parts of the body } \\
\hline Age & \multicolumn{1}{|c|}{ Description } & Answers \\
\hline $0-4$ years & $\begin{array}{l}\text { Shows: hair, hands, arms, legs, mouth, nose, ear, } \\
\text { back, knees, teeth. }\end{array}$ & 10 by 10 \\
\hline $4-5$ years & $\begin{array}{l}\text { Shows: cheen, forehead, chin, fingers, lips, tong, } \\
\text { shoulders, heels, nails. }\end{array}$ & 9 by 9 \\
\hline $5-7$ years & $\begin{array}{l}\text { Shows: lashes, punch, eyebrows, nostrils, pulp, eyelids, } \\
\text { ankle, hip language. }\end{array}$ & 7 by 10 \\
\hline
\end{tabular}

Table 2 Interpretation of the Test

\begin{tabular}{|l|l|l|l|l|l|l|l|l|l|l|l|l|l|}
\hline Age & 3 & 4 & 5 & 6 & 7 & 8 & 9 & 10 & 11 & 12 & 13 & 14 & 15 \\
\hline Point & 2 & 6 & 10 & 14 & 18 & 22 & 26 & 30 & 34 & 38 & 42 & 46 & 50 \\
\hline
\end{tabular}


Table 3 Results of initial test

\begin{tabular}{|l|l|}
\hline \multicolumn{2}{|l|}{ Goodenough Test } \\
\hline Initial test & 1 - head, 1 - eyes, 1 - nose, 1 - mouth, 1 - hair; \\
\hline Head & 1 - neck, 1 - continuum line; \\
\hline Neck & 1 - arms, 1 - proportion between them; \\
\hline Arms & 1 - body, 1 - clothes, 1 - without proportion; \\
\hline Body & 1 - legs, 1 - proportion, $1 ;$ \\
\hline Legs & 15 points \\
\hline Total &
\end{tabular}

Table 4 Result of final test

\begin{tabular}{|l|l|}
\hline \multicolumn{2}{|l|}{ Goodenough Test } \\
\hline Final test \\
\hline Head & $\begin{array}{l}1 \text { - head, } 1 \text { - eyes, } 1 \text { - pets, } 1 \text { - lashes, } 1 \text { - nose, } 1 \text { - mouth, } 1 \text { - lips, } \\
1 \text { - hair, } 1 \text { - ear; }\end{array}$ \\
\hline Neck & 1 -neck; \\
\hline Arms & 1 - arms, 1 - proportion between them, 1 - fingers; \\
\hline Body & 1 - body, 1 - without proportion, 1 - clothes, 1 - 2 pieces of clothes; \\
\hline Picioare & 1 - legs, 1 - proportion, 1 - legs nearby body. \\
\hline Total & 20 points \\
\hline
\end{tabular}

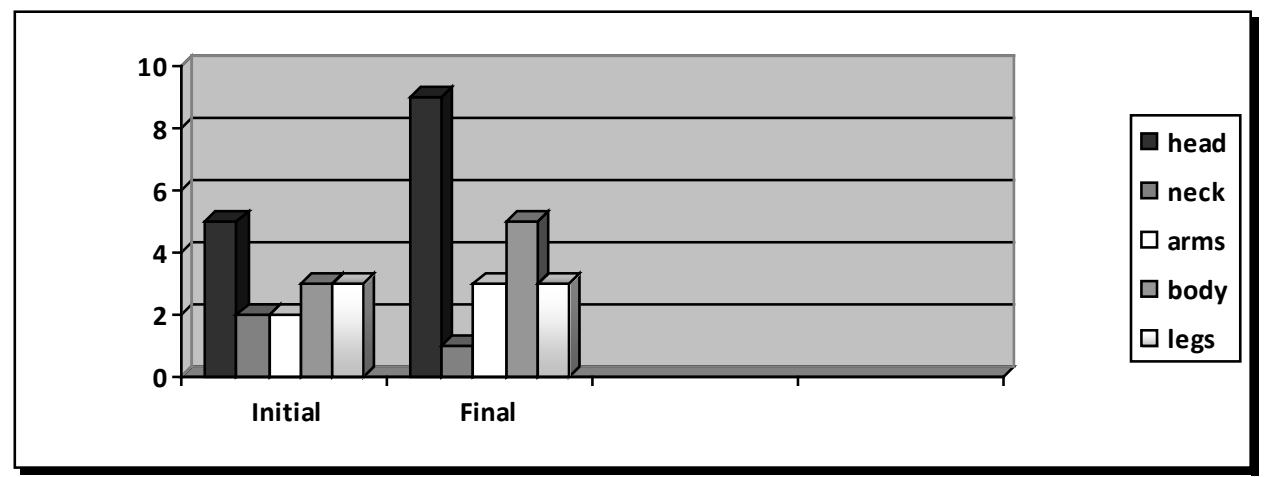

Figure 1. Representation of results

Old Studies using Goodenough test to identify the intelligence of children or to determine the level of disability (Kellmer Pringle, Pikup 1963 Phillips, Smith, Broadhurst, 1975), which led us to a simple study to correlate the body schema with the development of psychomotricity, according to standards set by national experts (as cited Abalaşei 2014, p. 51).

In this context, comparing benchmarks set by specialists with Goodenough test results we have noted a correlation between child elements designed in the drawing and indicators of motor behavior, socio-emotional, cognitive and verbal child's 6 years and 9 months old. 


\section{Conclusions}

The scheme is part of the body and is raising psychomotricity own body by which an individual differs from another.

Our intervention results show a balance between development and the child's body schema, according to drawings. This requires knowledge of body segments, certain postures and possible body movements in relation to people and objects in the environment. The level of body scheme development depends on the other components of psychomotricity: laterality, spatial-temporal structure, coordination etc. Through this work we emphasized the beneficial role of body scheme in the development of children. There isn't a new study, but it can be a starting point for identifying psychomotor disorders.

This research was based on application tests with which one can observe and monitor developments body scheme, and more. In this sense, after we applying these tests, can find the presence of disorder of body schema. These tests play an important role in prevention of disorders of body schema, if you have noticed some difficulties in performing the tasks required of the subject.

In conclusion, body scheme plays a crucial role in child development. This influences both the growth and the development of the individual. If the scheme is properly integrated body, the individual will develop harmoniously, but if there are disturbances of body schema, it can interfere with the growth and development of the child. Body scheme is an element underpinning the construction of individual personality, is vital to this process and enhancing self-esteem.

\section{References}

1. ABALAȘEI, B. (2014). Aplicații ale psihomotricităţii în fitness, curs, Iași: Edit. Universitatea Alexandru Ioan Cuza, 51.

2. ABRAHAM, A. (2004). Desenul persoanei. Testul Machover, București: Profex;

3. ALBU, A., ALBU, C. (1999). Psihomotricitatea la vârsta de creștere și dezvoltare, Iași: Spiru Haret, 8;

4. DE MEUR, STAES, L. (1988). Education et reeducation psychomotrices, Bruselles: De Boek;

5. GORDON, W. A. (1991). Structura și dezvoltarea personalității, București: Didactică și Pedagogică, 107;

6. KELLMER PRINGLE M. L., PIKUP, K. T. (1963). The reliability and validity of the goodenough draw-a-man test, DOI: 10.1111/j.20448279.1963.tb00592.x;

7. LAPIERRE, A. (1972). Le education physique, vol. 1, Paris: J.B. Bailliere, 81 ;

8. OCHIANĂ, G. (2006). Ludoterapia în recuperarea disabilităților psihoneuro-motorii ale copiilor, Iași: Edit. Performantica, 60;

9. PÁSZTAI, Z. (2004). Kinetoterapie în neuropediatrie, Oradea: ARIONDA, 157;

10. PHILLIPS, C. J, SMITH, BERYL, BROADHURST, ANNE. (1975). The 
draw-a-man test: a study of scoring methods, validity and norms with English children at five and eleven years, DOI: 10.1111/j.14697610.1973.tb01180.x;

11. WALLON, H. (1973). Evoluția psihologică a copilului, editura Didactică și Pedagogică, București, 47.

\title{
SCHEMA CORPORALĂ - COMPONENTĂ FUNDAMENTALĂ A CREȘTERII ȘI DEZVOLTĂRII
}

\author{
Abalașei Beatrice ${ }^{1}$ \\ Popescu Lucian ${ }^{2}$ \\ 1,2Universitatea „Alexandru Ioan Cuza” din Iasi, Toma Cozma, Nr. 3. 700584, România
}

Cuvinte cheie: psihomotricitate, schema corporală, creștere și dezvoltare

\section{Rezumat}

Schema corporală are un rol primordial în evoluția copilului. Aceasta influențează atât procesul de creștere, cât și cel de dezvoltare al individului. Dacă schema corporală este corect integrată, individul se va dezvolta armonios, dar dacă există tulburări ale schemei corporale, acestea pot influența negativ creșterea și dezvoltarea copilului. Schema corporală este un element ce stă la baza construirii personalităţii individului, fiind vital acestui proces și contribuind la creșterea stimei de sine. Demersul investigativ vine să demonstreze corelația dintre conturarea schemei corporale în acord cu maturizarea copilului. Afirmația anterioară este pemisa cercetării și va fi verificată prin intermediul a două teste. Rezultatele testelor sun relevante și trmit la atinfgerea obiectivului cercetării: o schemă corporală bine conturată favorizează localizarea în spaţiu, executarea unor acțiuni zilnice și relaționarea cu persoanele din jur.

\section{Introducere}

Schema corporală este, după F. Lauzon (1990 as cited in Albu, 1999, p. 64), imaginea corpului propriu, a locului său în spațiu și a posibilităților sale de acțiune în relație cu persoanele și obiectele din mediu.

Pentru R. Thomas, (1996) schema corporală este senzația de corporalitate, conștiința posturilor și atitudinilor fondată pe experiență și formată grație multiplelor informații intero și exteroceptive.”( as cited in Ochiană, 2006, p. 60). Unii autori pun semnul egal între schema corporală și imaginea corporală. În neurologie, prin imagine corporală se înțelege procesul de integrare la nivel cerebral a unei achiziții. Procesul de integrare implică identificarea, localizarea și orientarea în spațiu a diverselor segmente corporale. În acest caz este preferabilă utilizarea noțiunii de schemă corporală. Imaginea corporală se referă la modul de percepție a propriului corp, fiind un concept utilizat de psihologi.

Autorul H. Wallon (1973, p. 47) afirmă faptul că schema corporală este un element de bază indispensabil pentru construirea personalităţii copilului, este 
reprezentarea mai mult sau mai puțin diferențiată pe care copilul o are despre propriul corp. Definiția clasică dată de A. Porot (as cited in Albu \& Albu, 1999, p. 38) spune că schema corporală reprezintă ,imaginea pe care o are fiecare despre corpul său, imagine totală sau parțială, percepută în stare statică sau dinamică sau în raportul părților corpului între ele și, mai ales, a raporturilor acestuia cu spațiul și mediul încojurător”.

O schemă corporală bine elaborată favorizează localizarea în spaţiu, executarea unor acțiuni zilnice și relaționarea cu persoanele din jur. A. Lapierre (1972, p. 81) consideră că schema corporală apare prin punerea în concordanță a percepției proprioceptive, care dă imaginea internă a eului, și a celei exteroceptive (percepții vizuale, tactile și auditive), care oferă o imagine externă a eului. Această punere în concordanță apare în timpul experiențelor motrice ale primei copilării, când copilul dobândește prehesiunea și apoi, realizează mersul. Repetarea acestor experiențe duc la stabilirea și fixarea unei imagini corecte a corpului, imagine separată sau integrată în spațiul înconjurător. Relațiile „interperceptive” vor apărea în cadrul acestor experiențe motrice și vor favoriza detaşarea de motricitate pentru a forma gândirea abstractă.

Formarea schemei corporale depinde de: achiziţia orientării temporale, lateralitate, limbaj, imaginea reflectată. În acest sens, schema corporală reprezintă nu doar achiziția de date perceptive sau reprezentări, ea memorează informații pentru a defini unitatea corporală. Factorii determinanți ai schemei corporale sunt: informațiile senzoriale (senzații tactile, termice, dureroase), integrarea neurofiziologică, integrarea cognitivă (contribuția inteligenței motrice şi a proceselor mnemotehnice), înțelegerea propriei lateralități, rolul modelelor sociale în evoluția ontogenetică (factori sociali) și trăirile emoționale în relație cu corporalitatea (factori afectivi). Astfel, schema corporală este expresia creșterii și maturizării individului, este indicatorul care trimite la maturizarea ființei umane, la integrare ei în mediu și colaborarea cu el.

Prin procesul de creștere se înțelege nivelul cantitativ al indicatorilor somatici individuali, nivel influențat de acțiunea factorilor genetici și de mediu. Creșterea trebuie privită în toată complexitatea sa deoarece este o caracteristică de bază a organismelor vii.

Prin dezvoltare se înțelege nivelul calitativ al indicilor somatici individuali, nivel dependent de acțiunea factorilor ereditari și de mediu, în care educaţia are un rol important. Dezvoltarea trebuie privită ca o accentuare a complexității structurii și funcțiilor, ca o orientare către maturizare morfologică și funcțională. Procesul de dezvoltare se bazează pe anumite fenomene ce au loc la diverse nivele de organizare cum ar fi la nivelul celular, subcelular, tisular, la nivelul întregului organism, cât și la nivelul colectivității umane.” (Albu \& Albu, 1999).

„Dezvoltarea fizică a individului este strâns legată de bagajul motric al individului, format din priceperi, deprinderi și calităţi motrice, precum și armonie între indicii morfologici (somatici) și cei funcționali, proporționalitate între ei, aceștia conducând la indici superiori de dezvoltare morfologică și funcțională a organismului. În acest context, dezvoltarea intelectuală este 
responsabilă de achiziția de informații (forme de energii) care invadează simțurile, informații culese din mediul ambiant sau din cunoștințele anterioare (informații dobândite de părinți și transmise copiilor prin intermediul genelor). „Copilul este la început capabil numai de mișcări în bloc, de retragere sau apropriere globală sau de răsuciri și contorsionări întâmplătoare ale întregului corp. Din această matrice amorfă se desprind treptat activități mai fine.”(Gordon, 1991, p. 107).

Dezvoltarea reprezintă un proces complex de trecere de la necunoscut la cunoscut, de la simplu la complex, de la abstract la familiar, de la o treaptă inferioară la alta superioară, ce se desfășoară în diferite etape. Trecerea de la o etapă la alta se remarcă prin salturi calitative și acumulări cantitative, aceste fenomene aflându-se într-o relație de interdependență. Dezvoltarea are un caracter ascendent, asemănător unei spirale, cu stagnări și reveniri aparente. Fiind un proces progresiv, dezvoltarea este rezultatul acțiunii contradicțiilor ce apar mereu între capacitățile pe care le deține un individ, la un moment dat, și cerințele din ce în ce mai complexe evidențiate de factorii materiali și sociali ce influențează evoluția sa.

Dezvoltarea psihică este rezultatul interacțiunii factorilor externi și interni. Factorii externi sunt alcătuiţi din totalitatea acțiunilor și influențelor ce intervin din exterior asupra formării și dezvoltării personalității umane, și anume mediul și educația, iar cei interni se referă la totalitatea condițiilor care influențează dezvoltarea psihică, condiții care pot fi de natură biologică, ereditară.

\section{Material și metode}

Scopul lucrării Această lucrarea își propune să arate contribuţia schemei corporale în procesul de creștere și dezvoltare.

Ipoteza lucrării Considerăm că o schemă corporală corect integrată, vizibilă în proiectarea copilului, reflectă o creștere și dezvoltare normale.

Metoda Testul omulețului (Goodenough) oferă indicii despre nivelul intelectual al copilului și în functie de nivelul său de maturitate psihomotrică, de proiectarea sa în desenul unui omuleț, acești indici pot fi semnificativi pentru dezvoltarea cognitivă, evaluată concret prin gradul de perfecțiune și completitudine a desenului, echilibrul general, bogăţia detaliilor (Abraham, 2004).

Cerceterea de faţă s-a desfăşurat pe o perioadă de nouă luni de zile, între octombrie 2015 - iunie 2016 şi a avut ca subiect un copil de gen feminin, cu vârsta de 6 ani, din Iași.

S-au aplicat 2 serii de teste, inițial și final, pe baza cărora vom putea observa relația dintre evoluția schemei corporale și cea a copilului. Testare inițială: 15.02.2016. Testare finală: 10.06.2016

\section{Rezultate și discuții}

În cadrul acestui studiu am aplicat Testul omulețului, cu înregistrări ale rezultatelor inițiale dar și a celor finale, pentru a le compara și a observa rolul benefic al schemei corporale în dezvoltarea armonioasă a copiilor. 
Tabel 1. Goodenough - de cunoaștere a părților corpului

\begin{tabular}{|c|l|c|}
\hline \multicolumn{3}{|c|}{ Goodenough - cunoașterea părților corpului } \\
\hline Vârsta & \multicolumn{1}{|c|}{ Descrierea } & $\begin{array}{c}\text { Răspunsuri } \\
\text { corecte }\end{array}$ \\
\hline $0-4$ ani & $\begin{array}{l}\text { Arată: păr, mâini, picioare, gură, nas, urechi, } \\
\text { spate,burtă, genunchi, dinţi. }\end{array}$ & 10 din 10 \\
\hline $4-5$ ani & $\begin{array}{l}\text { Arată: obraz, frunte, barbă, gât, degete, unghie, } \\
\text { buze,umeri, călcâi. }\end{array}$ & 9 din 9 \\
\hline $5-7$ ani & $\begin{array}{l}\text { Arată: coate, gene, pumn, sprâncene, nări, } \\
\text { pulpă, pleoape, gleznă, şold, limbă. }\end{array}$ & 7 din 10 \\
\hline
\end{tabular}

Tabel 2 Proba Goodenough

\begin{tabular}{|c|c|c|c|c|c|c|c|c|c|c|c|c|c|}
\hline $\begin{array}{c}\text { Vârsta } \\
\text { E.M. }\end{array}$ & 3 & 4 & 5 & 6 & 7 & 8 & 9 & 10 & 11 & 12 & 13 & 14 & 15 \\
\hline Puncte & 2 & 6 & 10 & 14 & 18 & 22 & 26 & 30 & 34 & 38 & 42 & 46 & 50 \\
\hline
\end{tabular}

Tabel nr. 3. Rezultatele probei inițiale

\begin{tabular}{|l|l|}
\hline \multicolumn{2}{|c|}{ Testul Goodenough } \\
\hline \multicolumn{2}{|c|}{ Testare inițială } \\
\hline Cap & 1 - prezență, 1 - ochi, 1 - nas, 1 - gură, 1 - păr; \\
\hline Gât & 1 - prezență, 1 - linie continuă între cap și corp; \\
\hline Brațe & 1 - prezență, 1 - proporție; \\
\hline Trunchi & $\begin{array}{l}1-\text { prezență, } 1 \text { - prezența hainelor, 1 - lungimea este mai mare } \\
\text { decât lățimea; }\end{array}$ \\
\hline Picioare & 1 - prezență, 1 - proporție, 1 - membrele sunt atașate de trunchi; \\
\hline Total & \multicolumn{1}{c|}{15 puncte } \\
\hline
\end{tabular}

În urma testării finale am obținut următoarele rezultate grupate în tabel:

Tabel nr. 4. Rezultatele probei finale

\begin{tabular}{|l|l|}
\hline \multicolumn{2}{|c|}{ Testul Goodenough } \\
\hline \multicolumn{2}{|c|}{ Testare finală } \\
\hline Cap & $\begin{array}{l}1 \text { - prezență, 1 - ochi, 1 - pupile, 1 - gene, 1 - nas, 1 - gură, 1 - } \\
\text { buzele reprezentate prin 2 linii, 1 - păr, 1 - urechi; }\end{array}$ \\
\hline Gât & 1 - prezență \\
\hline Brațe & 1 - prezență, 1 - proporție, 1 - degete; \\
\hline Trunchi & $\begin{array}{l}1 \text { - prezență, 1 - lungimea este mai mare decât lățimea, 1 - } \\
\text { prezența hainelor, 1 - 2 piese vestimentare; }\end{array}$ \\
\hline Picioare & 1 - prezență, 1 - proporție, 1 - membrele sunt atașate de corp. \\
\hline Total & 20 puncte \\
\hline
\end{tabular}




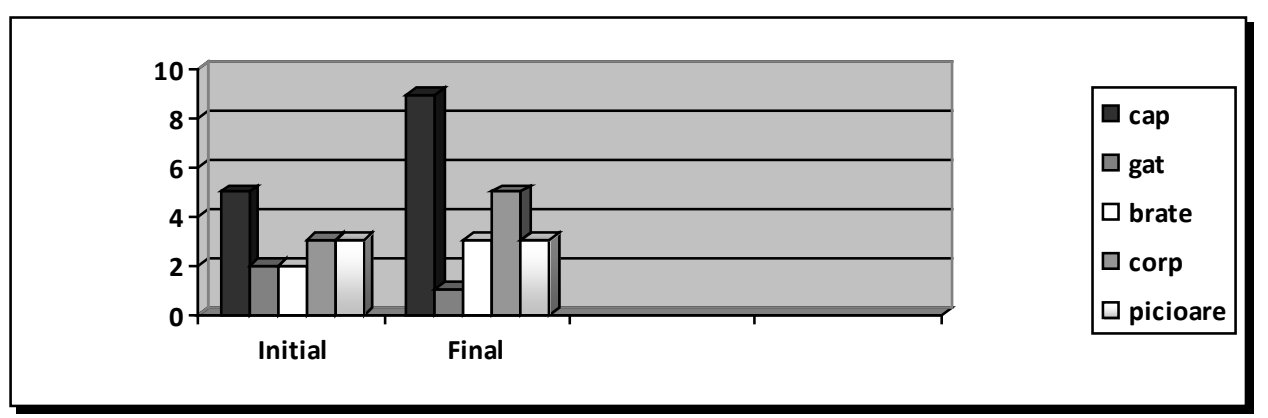

Figura 1. Reprezentarea rezultatelor

Studii vechi utilizează testul omulețului pentru a identifica nivelul inteligenței copiilor sau pentru a determina nivelul de disabilitate (Kellmer Pringle \& Pikup, 1963; Phillips, Smith, \& Broadhurst, 1975), ceea ce ne-a condus către un studiu simplu care să coreleze schema corporală cu nivelul dezvoltării psihomotrice, conform standardelor impuse de specialiștii autohtoni (as cited in Abalașei, 2014, p. 51). În acest context, s-au comparat reperele fixate de specialiști cu rezultatele la testul Goodenough și s-a remarcat o concordanță între elementele proiectate de copil în desen și indicatorii privind comportamentul motor, socio-afectiv, cognitiv și verbal al copilului de 6 ani și 9 luni.

\section{Concluzii}

Schema corporală este o componentă a psihomotricității și reprezintă conștientizarea propriului corp prin care un individ se deosebește de altcineva. Este reprezentarea pe care o are fiecare individ despre propriul corp în stare statică și dinamică. Aceasta presupune cunoașterea segmentelor corporale, a anumitor poziții ale corpului și a posibilelor mișcări ale corpului în relație cu persoanele și obiectele din mediul înconjurător. De nivelul de dezvoltare al schemei corporale depind și celelalte componente ale psihomotricității (structurarea spațio-temporală, coordonarea oculo-motorie).

Prin această lucrare am evidențiat rolul benefic al schemei corporale în dezvoltarea armonioasă a copiilor.

Această cercetare s-a bazat pe aplicarea testelor cu ajutorul cărora se poate observa și monitoriza evoluția schemei corporale și nu numai.

În urma aplicării acestor teste se poate constata prezența unor tulburări de schemă corporală. Aceste teste joacă un rol important și în prevenirea tulburărilor de schemă corporală, dacă s-au observat unele dificultăți ale subiectului în îndeplinirea sarcinilor cerute.

În concluzie, schema corporală are un rol primordial în evoluția copilului. Aceasta influențează atât procesul de creștere, cât și cel de dezvoltare al individului. Dacă schema corporală este corect integrată, individul se va dezvolta armonios, dar dacă există tulburări ale schemei corporale, acestea pot influența negativ creșterea și dezvoltarea copilului. Schema corporală este un element ce stă la baza construirii personalitătii individului, fiind vital acestui proces și contribuind la creșterea stimei de sine. 